\title{
ДИССЕРТАЦИОННЫЕ ИССЛЕДОВАНИЯ
}

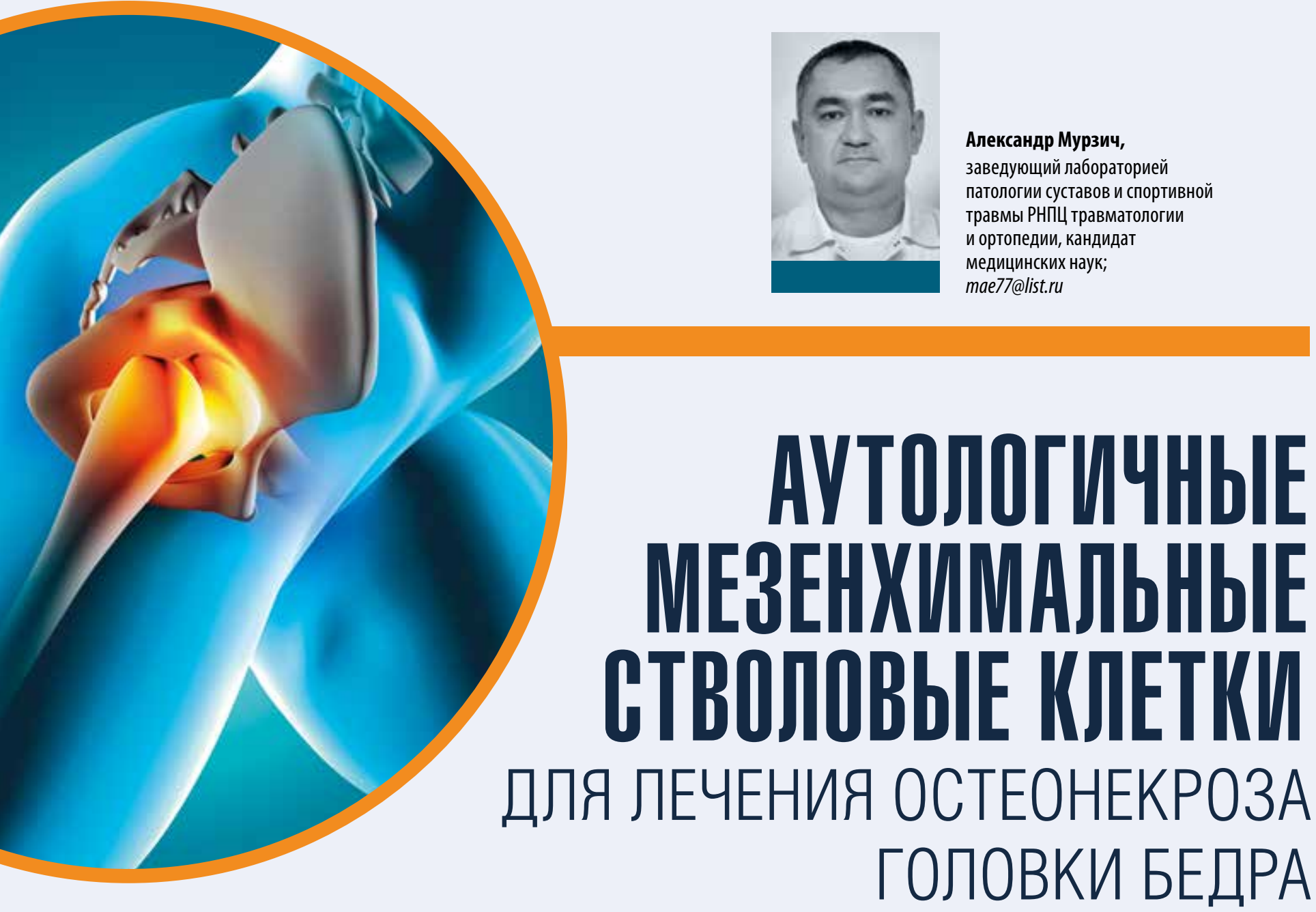

Аннотация. $B$ статье приведен анализ результатов 64 малоинвазивных операций при некрозе головки бедренной кости у взрослых. Описан протокол получения биомедицинского клеточного продукта в фибриновом геле, этапы хирургической трансплантачии. Результаты лечения оценены в сроки от 1 до 5 лет после операции.

Ключевые слова: некроз головки бедренной кости, мезенхимальные стволовые клетки, костная пластика.

Для цитирования: Мурзич А. Аутологичные мезенхимальные стволовые клетки для лечения остеонекроза головки бедра // Наука и инновации. 2020. №6. С. 78-83

https://doi.org/10.29235/1818-9857-2020-6-78-83

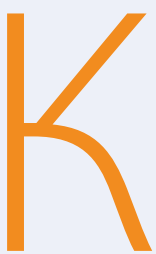

линическое применение клеточных технологий в лечении некроза головки бедренной кости (НГБК) - новое и молодое направление современной медицины, развиваемое в странах Европы и США. Для проведения клеточной терапии пациентам с НГБК первоначально в качестве трансплантата использовались нативный костный мозг или фракция мононуклеарных клеток костного мозга (МНК КМ) [1]. Обоснованием для использования мезенхимальных стволовых клеток (МСК) при НГБК явилась, с одной стороны, способность костномозговых МСК дифференцироваться в остеобласты, с другой - участие этих клеток в ангиогенезе и неоваскуляризации [2].

Родоначальники клеточной терапии Hernigou с соавторами (Франция) [3] перкутанно вводили концентрат МСК в очаг некроза головки бедра. Их стратегия обусловлена предположением, что ство- 
ловые клетки могут заселить трабекулярную структуру костной ткани, а затем оживить и реконструировать некротическую кость. Yan Z. (2009 г.) в своей работе показал, что трансплантированные МСК способны выживать, размножаться и дифференцироваться непосредственно в остеобласты, что способствует ускоренному процессу восстановления [4].

Наряду с успехами имеется ряд нерешенных вопросов. Протокола получения биотрансплантата МСК для клинического применения с целью регенерации костной ткани, несмотря на активно ведущиеся исследования, в настоящее время не существует. Отсутствует также детальное описание хирургических способов имплантации МСК. В связи с этим разработка принципиально нового лечебного подхода с использованием метода аутотрансплантации мезенхимальных стволовых клеток имеет несомненную научную новизну и практическую значимость.

\section{МАТЕРИАЛЫ И МЕТОДЫ}

В клинике РНПЦ травматологии и ортопедии разработан системный подход к лечению НГБК у взрослых с применением аутотрансплантации МСК. Методика предполагала проведение дифференцировки и созревания МСК in vitro и включала следующие основные этапы (рuс. 1):

- предоперационное обследование и планирование (на основании разработанного алгоритма диагностики (инструкция по применению, утверждена Минздравом Республики Беларусь, рег. № 089-1116 om 14.04.2017 г.);

- эксфузия костного мозга пациентов в объеме 50-70 мл для последующего получения культуры клеток за 4 недели до имплантации;

- этап остеогенной дифберенцировки и получения «имплантата»: выделение МСК и экспансия ауто МCK in vitro в течение 3-4 недель в культуральной среде, получение биомедицинского клеточного продукта (БМКП МСК) для дальнейшей имплантачии в очаг некроза;

- этап аутотрансплантации МСК: БМКП МСК, предварительно помещенный на искусственный носитель, вводился в зону некроза головки бедра согласно инструкиии по применению (рег. № 0540419 om 17.05.2019 г.);

- послеоперационная реабилитация и наблюдение. Эксфузия костного мозга. Для проведения забора костного мозга пациент госпитализировался в клинику РНПЦТО после предоперационного обследования. В условиях операционной под внутривенной анестезией выполняли пункцию крыла подвздошной кости. Для этого прокалывалась его наружная кортикальная пластинка на 2 см сзади от передневерхней кости с помощью троакара. Он вводился на глубину 2-3 см в толщу подвздошной кости. К игле присоединяли шприц, с помощью которого аспирировали костный мозг в объеме 50-70 мл. Далее его пунктат в пробирке с антикоагулянтом в стерильных условиях транспортировался в лабораторию РНПЦ детской онкологии, гематологии и иммунологии (РНПЦДОГИ) для получения культуры клеток. Пациент выписывался на 4 недели.

Получение биомедицинского клеточного продукта. В лаборатории клеточных биотехнологий и цитотерапии РНПЦДОГИ осуществлялось выделение МСК методом адгезии к пластику из фракции мононуклеарных клеток костного мозга с дальнейшим их культивированием, с оценкой их подлинности по иммунофенотипическим маркерам и жизнеспособности, а также стерильности биомедицинского клеточного продукта мезенхимальных стволовых клеток.

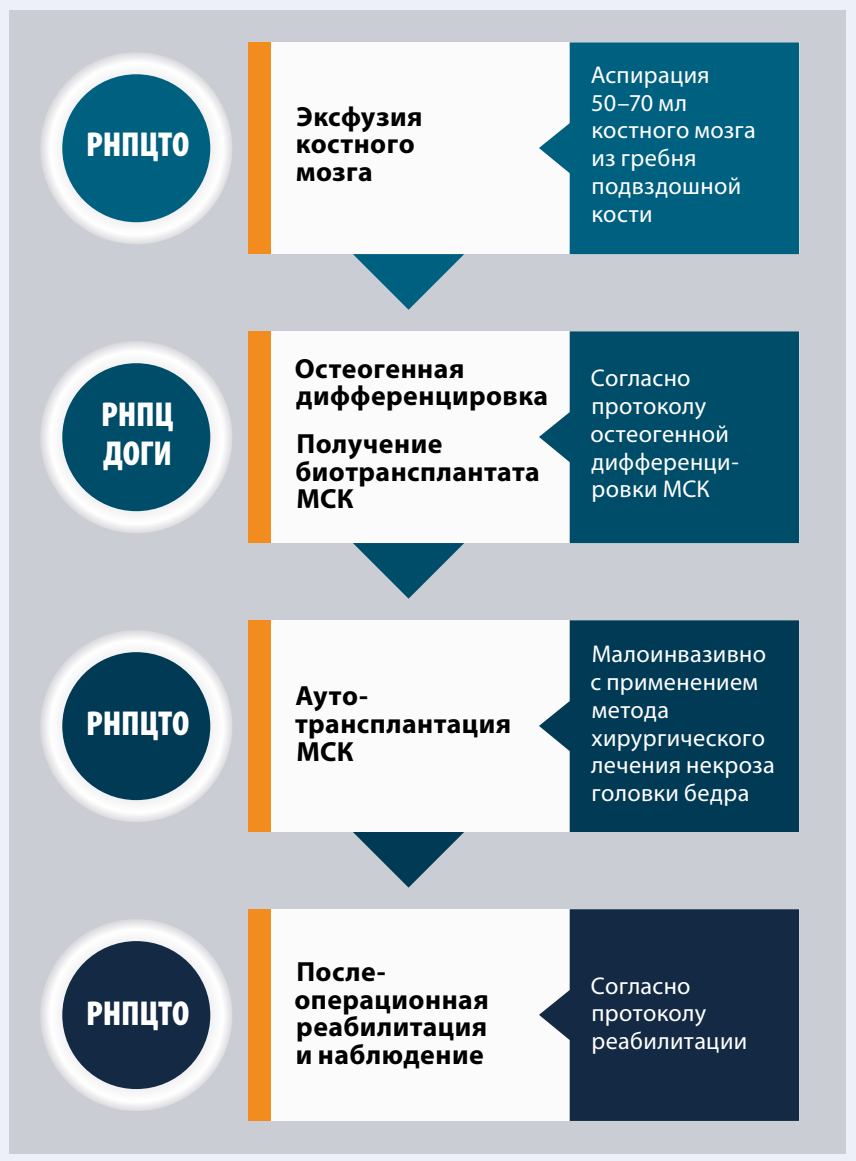

Рuc. 1. Дизайн хирургической аутотрансплантации МСК при НГБК у взрослых 
В качестве носителя для клеток был использован фибриновый гель [5], создание композита БМКП МСК в котором для заполнения области некроза пациента включало получение фибринового геля, внесение клеточного продукта МСК пациента, перенос композита в дифференциальную среду и культивирование клеток в $\mathrm{CO}_{2}$-инкубаторе в течение 4-5 дней. Приготовленный БМКП МСК использовался в течение 2 часов после получения.

При эксфузии в среднем $67,5[55 ; 72,5]$ мл костного мозга у пациентов с НГБК в течение 33 [30; 36,5] суток экспансии клеток в культуре получено в среднем $29[26 ; 35,5] \times 10^{6}$ аутологичных МСК. Анализ клеточного материала на стерильность бактериальной контаминации не обнаружил. Иммунофенотипический анализ подтвердил, что все полученные клеточные продукты содержали более 96\% жизнеспособных клеток, экспрессирующих маркеры МСК: CD90-98,6 [95,08; 99,45]\%, CD73-97,97 [96,99; 98,8]\%, CD105-98,23 [87,6; 99,01]\%.

Приведем пример гистологического анализа срезов трансплантируемого композита пациента К. Оценка показала, что в поле зрения наблюдался эозинофильный матрикс с большим количеством рассеянных клеток. Клетки крупные с широкой округлой эозинофильной цитоплазмой и эксцентричным мелким ядром (рuс. 2 Б). Заселенные клетки распределялись в толще носителя плотно и достаточно равномерно (рис. 2 A).

Для имплантации клеточного продукта пациент госпитализировался в РНПЦТО после изготовления биотрансплантата. В день операции осуществлялась транспортировка БМКП МСК из лаборатории клеточных биотехнологий и цитотерапии.

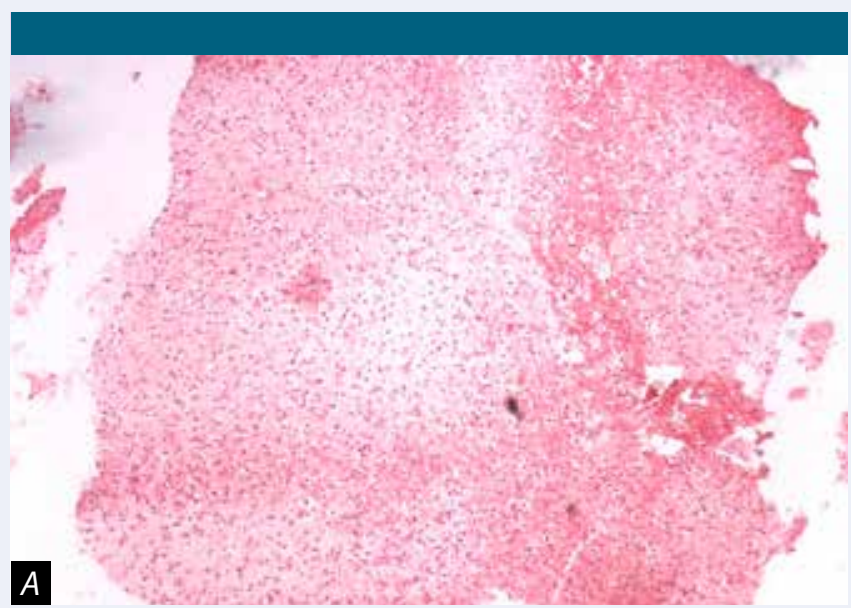

Хирургическое вмешательство включало в себя 2 этапа - декомпрессию очага некроза и трансплантацию МСК.

Первый этап проходил в соответствии с разработанным методом хирургического лечения остеонекроза головки бедра, изложенным в инструкции по применению (рег. №197-1115 от 20.05.2016 г.). После выполнения декомпрессии биотрансплантат МСК извлекался из среды для культивирования непосредственно во время операции и вводился в зону некроза с помощью поршневидного толкателя. Для предотвращения вытекания трансплантата при имплантации пациент поворачивался под углом $30^{\circ}$ на противоположный бок с помощью моторизированного операционного стола, наружная часть костного канала обтурировалась костной аутопробкой с целью гемостаза и предотвращения вытекания БМКП МСК.

После выполнения декомпрессивных вмешательств, включая применение МСК, на 2-е сутки после операции разрешалась ходьба с помощью костылей с дозированной нагрузкой на оперированную конечность до 10\% веса тела (4 недели), затем нагрузку постепенно увеличивали до полной в течение 14 дней.

Нами проанализированы 64 случая малоинвазивных операций, выполненных 60 пациентам при НГБК с применением разработанных оригинальных технологий. В группу А включены 42 пациента, которым произведена малоинвазивная декомпрессия очага некроза головки бедра с костной аутопластикой (42 операции). В группу Б включены 18 пациентов, которым выполнены 22 малоинвазивные декомпрессии с введением в очаг некроза кон-

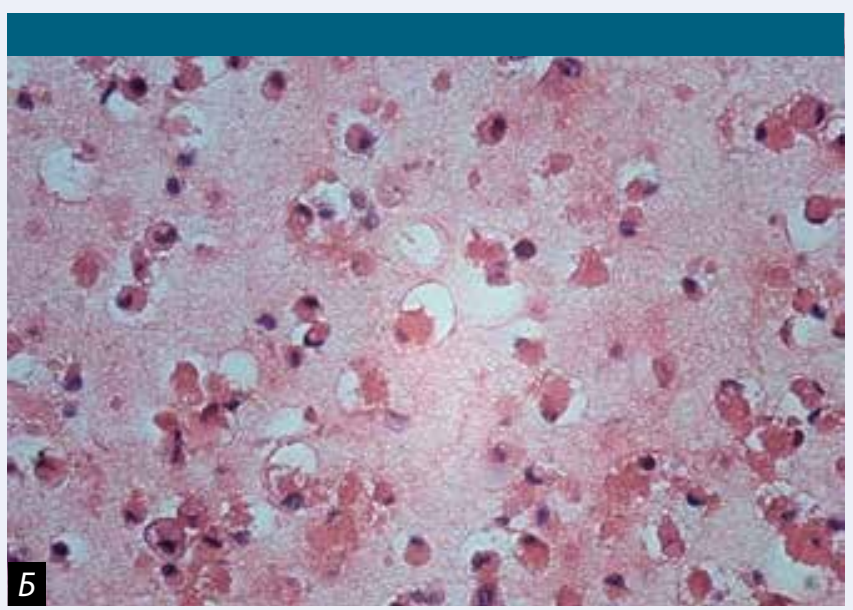

Puc. 2. Гистологический срез биокомпозита МСК в фибриновом геле для пациента К. А - увеличение 40, Б - увеличение 600 
центрата аутологичного костного мозга и мезенхимальных стволовых клеток; 4 пациента в группе Б оперированы с обеих сторон. Распределение пациентов по стадиям заболевания согласно классификации ARCO [6] представлено в табл. 1. Группы пациентов были сопоставимы по полу и возрасту, средний возраст оперированных составил $40[30 ; 47,5]$ лет.

Наибольшее количество случаев в проанализированном материале соответствовало поздним стадиям остеонекроза (IIc и IIIa) с распространением некротической зоны латеральнее наружного края вертлужной впадины (46 случаев, 72\%).

В группе А зона некроза заполнялась с помощью измельченной аутогубчатой кости. Импакционную костную пластику губчатой костью производили малоинвазивно через разрез кожи 3 см по запатентованной методике [7].

В группе Б в 10 случаях перед декомпрессией выполняли пункцию крыла подвздошной кости с помощью троакара. Аспирировали костный мозг в объеме 60-80 мл, центрифугировали и выделяли фракцию мононуклеарных клеток, объем которой доводили до 2-3 мл. После декомпрессии полученный концентрат МНК вводили с помощью длинной иглы внутрикостно через канал в головку бедра, смешивая с аутогубчатой костью. Нужно отметить, что при введении жидкой части МНК имело место вытекание клеточного продукта из внутрикостного канала, несмотря на использование аутокостной пробки. В группе Б 12 пациентам в очаг некроза вводили БМКП МСК в фибриновом геле.

Клеточная терапия применялась у пациентов в возрасте 25-45 лет, у которых были исключены бактериальные и инфекционные триггеры заболевания и установлена сосудистая этиология остеонекроза.

Результаты хирургического лечения пациентов проанализированы в сроки от 1 до 5 лет, средние сроки наблюдения составили 20 [12; 39,5] месяцев. Выявлены значимые различия в длительности госпитализации пациентов $(10[8 ; 14]$ в группе A и $8[6 ; 10]$ в группе $\mathrm{B}, \mathrm{p}=0,013)$. При использовании клеточных технологий пациенты госпитализировались накануне операции в связи с необходимостью имплантации клеточного продукта в ближайшее время после его дифференцировки. Послеоперационный период сокращался за счет эффективного купирования болей после вмешательства. Снижение болевого синдрома с $60 \pm 4,2$ до $32 \pm 3,4$ баллов по 100-балльной шкале ВАШ [8] отмечено в $40(62,5 \%)$ случаях, что, по нашему мнению, связано с падением внутрикостного давления в некро-

\begin{tabular}{|c|c|c|}
\hline Стадия & Количество случаев & $\%$ \\
\hline la & 3 & 5 \\
\hline Ila & 2 & 3 \\
\hline IIb & 13 & 20 \\
\hline IIC & 20 & 31 \\
\hline IIla & 26 & 41 \\
\hline Всего & 64 & 100 \\
\hline
\end{tabular}

Таблица 1. Распределение пациентов по стадиям заболевания

тическом очаге за счет декомпрессии и разгрузки сустава. Уровень болевого синдрома уменьшался на протяжении 3 месяцев после операции и затем существенно не менялся (р>0,05). В 30 (47\%) случаях пациенты, у которых по данным МРТ до операции определялся отек костного мозга всей головки с распространением на шейку бедра, после вмешательства отмечали купирование болей на 2-3 сутки после операции. Среднее число баллов по шкале Harris [9] у пациентов до операции составило 76 $\pm 5,2$, в послеоперационном периоде - 82,2 23,2 . Проведенный статистический анализ не выявил достоверных отличий в уровне болевого синдрома, определяемом по шкале ВАШ среди групп А и Б (р>0,05). Однако установлено, что выживаемость тазобедренных суставов при выполнении операций с использованием малоинвазивных клеточных технологий оказалась заметно лучше, чем при использовании только костной пластики $(\mathrm{p}<0,5)$. Статистически

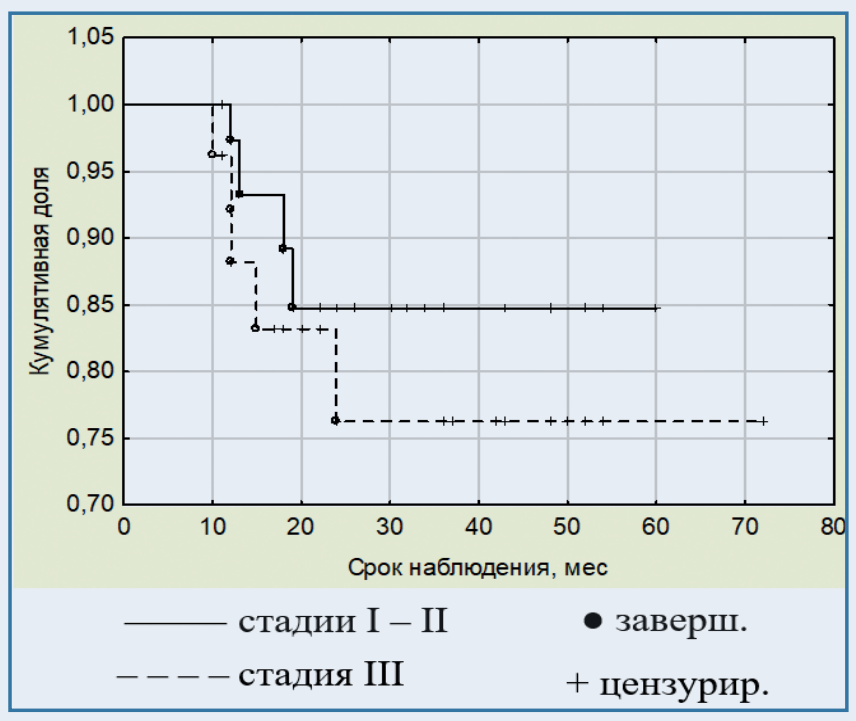

Рис. 3. Показатели успеха между стадиями остеонекроза в соответствии с методом Каплана - Мейера 


\section{ДИССЕРТАЦИОННЫЕ ИССЛЕДОВАНИЯ}

Рис. 4. Рентгенограммы пациентки Л. с НГБК до и через 5 лет после декомпрессии с использованием клеточных технологий лечения

А, Б-остеонекроз головки бедра III стадии с коллапсом головки 1 мм

В, Г- через 5 лет после применения клеточных технологий: незначительное прогрессирование остеонекроза, коллапс головки 2 мм, сферичность головки в проекции по Lauenstein сохранена, гипертрофия кортикального слоя обозначена стрелкой
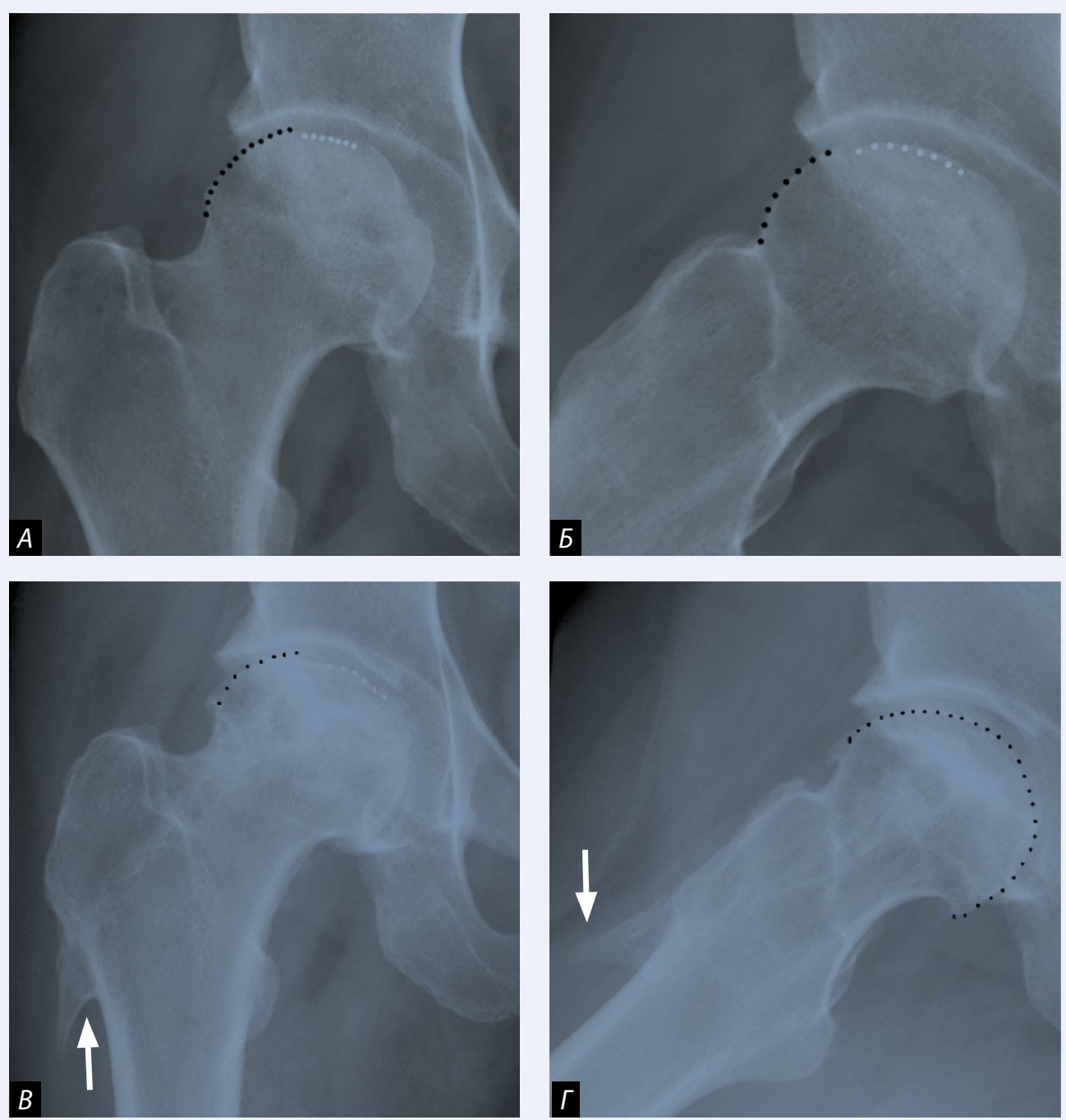

частота выполнения тотального эндопротезирования тазобедренного сустава (ТЭТС) после применения разработанных органосохранных операций на стадиях I-II остеонекроза оказалась заметно ниже, чем на стадии III ( $<<0,15)$ (рuс. 3).

Тотальному эндопротезированию были подвергнуты 9 (14\%) из 64 прооперированных тазобедренных суставов в сроки от 1 до 2 лет после операции. Различия в сроках выполнения ТЭТС в исследуемых группах были статистически незначимы $(\mathrm{p}=0,38$, по U=критерию Манна - Уитни). Среднее число баллов по шкале Harris в контрольной точке исследования составило 63,2 [59,8; 66,6], рентгенологически определялось прогрессирование коллапса головки и усиление болей. Обращает на себя внимание тот факт, что органосохранное вмешательство при этом выполнялось на IIс и IIIа стадиях заболевания из-за поздней диагностики остеонекроза и несвоевременного начала лечения. Кроме того, ряд пациентов не соблюдал рекомендации по послеоперационному режиму дозирования нагрузки. При использовании мезенхимальных стволовых клеток ТЭТС выполнено лишь единожды на момент оценки результатов. Во всех случаях послеоперационные изменения шейки и головки бедра не повлияли на выбор бедренного компонента эндопротеза и хирургического доступа.

Оценивая клинико-рентгенологические результаты лечения пациентов установлено, что процентное соотношение неудач в группе А выше, чем в группе Б, где был применен концентрат костного мозга (38,7\% и $26,7 \%$ соответственно). В группе с использованием клеточных технологий прогрессирование остеонекроза с отрицательной динамикой было на 12\% меньше, чем при костной пластике. Учитывая, что группы различались лишь по количественному признаку, можно сделать вывод о том, что клеточные технологии более предпочтительны. 
Эти результаты сопоставимы с данными, опубликованными другими авторами, в частности работами Hernigou, Zhao, Pak [10-12].

В 7 (11\%) случаях при использовании клеточных технологий в отдаленном периоде рентгенологически выявлена «пикообразная» гипертрофия наружного кортикального слоя бедренной кости в месте введения клеточного продукта. Это отмечалось как после применения МНК, так и БМКП МCК. На наш взгляд, такая гипертрофия костной ткани, не сопровождающаяся отрицательными клиническими проявлениями, выступает показателем активного костеобразования в зоне введения остеогенных клеток (рuc. 4). В группе, где была применена костная пластика, гипертрофия костной ткани не наблюдалась.

Анализ результатов выполненных нами вмешательств показал, что предложенные варианты органосохранных операций дают положительный долгосрочный клинико-рентгенологический результат при стадиях остеонекроза головки бедренной кости I, IIA, IIB, IIC, позволяют отдалить время вероятного эндопротезирования тазобедренного сустава.

Костнопластические вмешательства на стадии IIIA и IIIB дают хороший клинический результат с купированием болевого синдрома в раннем послеоперационном периоде. Тем не менее восстановление нагрузочной зоны головки требует костнопластических методов в паре со структурными трансплантатами или имплантами, которые способны выполнять поддерживающую функцию.
Клеточная терапия особенно эффективна для запуска процесса регенерации некротической области. Как показала практика, использование аутологичных клеток костного мозга, как дополнение к основному вмешательству, сопровождается потерей клеточной массы из-за вытекания продукта. Более оптимальным в качестве органосохранного вмешательства является применение для лечения остеонекроза головки бедра мезенхимальных стволовых клеток, стимулированных к дифференцировке в остеогенном направлении в составе фибринового геля. Методика позволяет создать благоприятные условия для регенерации костной ткани. При этом отмечается купирование болевого синдрома на фоне сохранения функции тазобедренного сустава и структуры головки бедра.

При соблюдении технологии, использование клеточных методов лечения не влечет за собой инфекционных, аллергических или иных осложнений.

- Summary. Analysis of the results of 64 minimally invasive surgeries for femoral head necrosis in adults was carried out. The protocol for producing a biomedical cell product in a fibrin gel, the stages of surgical transplantation are described. The results of treatment were evaluated in the period from 1 to 5 years after surgery.

Keywords: femoral head necrosis, mesenchymal stem cells, bone grafting.

https://doi.org/10.29235/1818-9857-2020-6-78-83

\section{СПИСОК ИСПОЛЬЗОВАННЫХ ИСТОЧНИКОВ}

1. Treatment of osteonecrosis of the femoral head by percutaneous decompression and autologous bone marrow mononuclear cell infusion / Yan Z.Q. [et al.] // Chinese journal of traumatology. 2006. Vol. 9. N1. P. 3-7.

2. Bone marrow stem cells: nature, biology and potential applications / Bianco P. [et al.] // Stem Cells. 2001. N19. P. 180-192.

3. Core decompression with marrow stem cells / Hernigou P. [et al.] // Oper. Tech. in Orthop. 2004. Vol. 14. N2. P. 68-74.

4. Fate of mesenchymal stem cells transplanted to osteonecrosis of femoral head / Yan Z. [et al.] // J. of Orthop. Res. 2009. Vol. 27. N4. P. 442-446.

5. Жерносеченко А. Выбор носителя и условий дифференцировки мезенхимальных стволовых клеток для восстановления костной ткани / Жерносеченко А., Исайкина Я., Михалевская Т. // Наука и инновации. 2019. №5. С. 58-61.

6. ARCO (Association Research Circulation Osseous) / Committee on terminology and classification // ARCO News. 1992. N4. P. 41-46.

7. Способ хирургического лечения аваскулярного некроза головки бедра у взрослого: пат. ВҮ 22648 / Белецкий А.В., Мурзич А.Э.- 0публ. 30.10.2018.

8. McCormack H.M. Clinical applications of visual analogue scales: a critical review / McCormack H. M., Horne D.J., Sheather S.// Psychological Medicine. 1988. Vol.18. N4. P. 1007-1019.

9. Harris W.H. Traumatic arthritis of the hip after dislocation and acetabular fractures: treatment by mold arthroplasty. An end-result study using a new method of result evaluation / Harris W.H. // J. Bone Joint Surg. Am. 1969. Vol.5. N4. P. 737-55.

10. Hernigou P., Poignard A., Rouard H. Cell therapy of hip osteonecrosis with autologous bone marrow grafting. Indian journal orthopaedics. 2009. Vol. 43. N1. P. 40-45.

11. Zhao D., Cui D., Wang B., et al. Treatment of early stage osteonecrosis of the femoral head with autologous implantation of bone marrow-derived and cultured mesenchymal stem cells. Bone. 2012. Vol. 50. N1. P. 325-330.

12. PakJ. Autologous adipose tissue-derived stem cells induce persistent bone-like tissue in osteonecrotic femoral heads: a molecular mechanism. Pain Physician. 2012. Vol.15. N1. P. 75-85. 